\title{
RESPONSABILIDADE CIVIL DO PODER PÚBLICO PELO MANEJO INDEVIDO DE AÇÃO DE IMPROBIDADE ADMINISTRATIVA
}

\author{
MAURO ROBERTO GOMES DE MATTOS*
}

I- O uso da jurisdição deve ser responsável; $I I-$ Abuso do Ministério Público ou do órgão público do direito de acionar; III - Da responsabilidade civil do açodado denunciante; IV - Conclusão

\section{I-O uso da jurisdição deve ser responsável}

O Poder Público, em todos os níveis, possui como missão principal possibilitar à sociedade o seu desenvolvimento justo e honesto, em homenagem à segurança jurídica que deve inspirar a atuação dos países que marcham sob os desígnios da bandeira do Estado Democrático de Direito.

Exatamente por essa órbita legal o poder não é ilimitado, não podendo a lei excluir da apreciação do Poder Judiciário lesão ou ameaça a direito (art. $5^{\circ}, \mathrm{XXXV}$, da CF).

Desse modo, o Estado, no desempenho de sua finalidade de assegurar a ordem jurídica, não pode ser irresponsável na sua atuação, tendo em vista que, como parte, representado por um dos seus entes públicos, deve trazer para a sociedade a segurança de que não perseguirá pessoas ou grupos com a propositura de ações temerárias, que trazem no seu âmago o espírito da perseguição ou da vingança política.

A jurisdição é o poder que nasce direcionado para o Estado, para que ele possa fazer valer a regra jurídica, uma vez que, através do Poder Judiciário, é o responsável pela estabilização das relações sociais, do cumprimento obrigatório das leis.

* Advogado no Rio de Janeiro. Autor dos Livros $O$ Contrato Administrativo $-2^{\mathbf{a}}$ ed., Ed. América Jurídica, e $O$ Limite da Improbidade Administrativa - $O$ Direito dos Administrados dentro da Lei $n^{\circ} 8.429 / 92$, Ed. América Jurídica. Vice-Presidente do Instituto Ibero-Americano de Direito Público - IADP, Membro da Sociedade Latino-Americana de Direito do Trabalho e Seguridade Social, Membro do IFA - Internacional Fiscal Association. Conselheiro efetivo da Sociedade LatinoAmericana de Direito do Trabalho e Seguridade Social. 
Assim, quando o Poder Público, responsável pela jurisdição, alça a condição de autor de ação judicial, ele terá que ter como finalidade a manutenção do postulado ético-jurídico da lealdade processual, onde o processo não poderá ser manipulado para viabilizar o abuso de direito.

In casu, o abuso de direito se verifica quando o poder público exerce a sua faculdade de acionar agente público, com base na Lei de Improbidade Administrativa, sem que haja um mínimo de indício da prática de um ato devasso.

Para situarem-se no campo da normalidade e da licitude, não basta a parte estar legitimada pela legislação para utilizar-se da via judicial, pois é necessário um mínimo de materialidade de determinado fato ilícito/devasso, sob pena de estar caracterizada a intenção de causar mal a outrem.

Ainda mais quando se verifica que a Lei de Improbidade Administrativa causa danos irresgatáveis para os agentes públicos injustamente processados.

Mesmo que o Agente Público seja inocentado a posteriori, ao término da morosa lide, o dano à sua imagem e a moral ficam entranhados no meio social que ele convive, pois a cada dia que passa existe a dor de quem se vê alçado à injusta condição de réu.

Por essa razão, o ação de improbidade administrativa deve ser proposta após a inequívoca evidência de que a irregularidade funcional vislumbrada, em tese, constitui ato de devassidão, enquadrável na Lei $\mathrm{n}^{\circ} 8.429 / 92$.

No curso dos anos presenciamos várias ações de improbidade administrativa genéricas, instauradas sem elementos de apoio, para, a posteriori, ser feita uma devassa na vida do agente público, com o objetivo de apená-lo, mesmo que inexistentes indícios de irregularidades.

Além de discriminatório, esse tipo de conduta merece o devido repúdio por parte do direito, que não admite desvios ou excesso de poder por parte da Administração Pública.

Nessa moldura, o constituinte moderno, na luta entre a repressão de ilícitos e a proteção da honra, imagem, bom nome e privacidade, traçou a devida fronteira de atuação do Poder Público, que deverá atuar dentro dos limites estabelecidos pela Magna Carta.

E coube ao art. $5^{\circ}$ da $\mathrm{CF}$ e seus incisos distribuir diversos dispositivos que disciplinam o processo; a pena; a aplicação da pena e as condições para seu cumprimento (incs. XXXIX e seguintes); a inviolabilidade da intimidade, da honra e da imagem e da vida privada (inc. X); o direito de indenização do dano moral, material e à imagem (inc. V); defesa da intimidade restringida a publicidade de atos processuais (inc. LX); o direito de defesa (inc. LV) e o direito de propriedade (inc. LIV), dentre outras.

Mantendo inafastáveis e intactos tais direitos, o art. $60, \S 4^{\circ}, I V$, da CF proíbe que eles, inseridos nas garantias fundamentais da sociedade (art. $5^{\circ}$ ), sejam objetos de deliberações de proposta de emenda constitucional tendente a aboli-los com a retirada do texto constitucional.

Pois bem, a garantia mínima do cidadão de que não será molestado, sem o devido processo legal, e que o procedimento instaurado conterá indício da prática de um ato vedado pelo ordenamento jurídico vigente é uma realidade, pois se também 
existam dois conjuntos de normas constitucionais - os que propugnam a investigação e punição de ilícitos e os que protegem a honra e a imagem das pessoas - o certo é que o direito reconhece e cria instrumentos aptos que evitam danos inúteis à imagem das pessoas quando não haja elementos de suspeitas suficientes para constranger as pessoas a determinados procedimentos.

Os procedimentos disciplinares e os judiciais entram também nessa escalada, pois é vedada a instituição de inquérito disciplinar genérico, em que acusações vagas servem para iniciar uma devassa na vida do agente público no afã de encontrar-se prova de pseudoconduta ilícita.

Não é lícito e nem factível que ainda ocorram acusações genéricas contra a honra de quem quer que seja. O direito não permite procedimentos de caráter aberto, sem que haja justa causa, contra agentes públicos que renderão ou não espaço na mídia contra seus nomes.

Essa garantia de inviolabilidade da intimidade, da honra e da imagem das pessoas retira do ente público a discricionariedade de instaurar procedimento disciplinar contra servidor público sem um mínimo de indícios ou plausibilidade de acusação. Não se admite a acusação genérica, sem justa causa:

"Com efeito, a necessidade de justa causa para a procedibilidade da denúncia tem o propósito de não submeter o indivíduo a uma situação que expõe sua reputação e imagem se não houver elementos suficientes consistentes que indiquem sua necessidade." 1

Necessariamente deverá estar presente o justo motivo, não só para a propositura de ação penal, como também para instauração do processo de improbidade administrativa correspondente, pois nessa última situação também não se admite a turbação da honra, da intimidade e da imagem do agente público, que possui na $\mathrm{CF}$ o antídoto necessário para curar chagas de injustiça perpetradas pelo Poder Público.

Alexandre de Moraes, em feliz síntese, grafa que a proteção constitucional da intimidade e da honra se estende a todos os relacionamentos da pessoa, inclusive as relações de trabalho:

"Os conceitos constitucionais de intimidade e vida privada apresentam grande interligação, podendo, porém, ser diferenciada por meio da menor amplitude do primeiro, que se encontra no âmbito de incidência do segundo. Assim, o conceito de intimidade relaciona-se às relações subjetivas e de trato íntimo da pessoa humana, suas relações familiares e de amizade, enquanto o conceito de vida privada envolve todos os relacionamentos da pessoa, inclusive os objetivos, tais como relações comerciais, de trabalho, de estudo, etc.

1 Luís Roberto Barroso, Temas de direito constitucional, tomo II, Renovar, 2002, p. 553. 
Encontra-se em clara e ostensiva contradição com o fundamento constitucional da dignidade da pessoa humana (CF, art. $1^{\circ}$, III), com o direito à honra, à intimidade e vida privada $\left(\mathrm{CF}\right.$, art. $\left.5^{\circ}, \mathrm{X}\right)$, converter em instrumento de diversão ou entretenimento assuntos de natureza tão íntima quanto falecimentos, padecimentos ou quaisquer desgraças alheias que não demonstrem nenhuma finalidade pública e caráter jornalístico em sua divulgação." 2

Portanto, a intimidade se relaciona diretamente com toda a vida privada do indivíduo, inclusive a suas relações de serviço, que são preservadas em homenagem à honra e à boa imagem de que devem desfrutar todos os homens de bem.

Falta de objeto é sinônimo de ausência de justa causa. Sendo certo que somente a irregularidade, recheada de elementos sólidos e concretos, é que poderá ser investigada, sem que haja constrangimento ilegal da honra e da intimidade do agente público.

Isso porque, mesmo o Estado tendo uma supremacia especial sobre os seus agentes públicos, não pode iniciar um processo punitivo sem que ocorra uma justa causa, consubstanciadas em provas e fatos legítimos que indiquem o cometimento de uma infração reprimida pela Lei de Improbidade Administrativa.

Se não houver falta disciplinar, materializada de forma contundente, é retirada da Administração Pública a faculdade de violar a intimidade do agente público.

A falta de indícios da prática de um ilícito retira da administração a sua faculdade discricionária de instauração de procedimento investigatório:

"Direito processual penal. Inquérito. Crimes previstos nos arts. 140 e 331 do Código Penal. Imputação ao Juiz do Trabalho. Inexistência de indícios da prática de quaisquer dos delitos invocados pelo Ministério Público Federal. Pedido de arquivamento. - Requerimento do Ministério Público Federal para arquivamento do inquérito policial instaurado, objetivando apurar a possível prática dos crimes de injúria e desacato pelo Juiz da $2^{\mathrm{a}}$ Vara do Trabalho de Volta Redonda. - Não configurada a prática de quaisquer dos crimes imputados ao Magistrado, eis que restou evidenciada a correta condução do processo, diante das argumentações trazidas pelas partes litigantes e de acordo com a fase processual que se apresentava. Reconhecido que os argumentos despendidos pelo patrono da reclamada não passam de assertivas utilizadas de forma enfática na defesa dos interesses de sua constituinte. - Art. 28 do Código de Processo Penal. - Arquiva-. mento feito, por faltar justa causa necessária ao exercício da ação penal". ${ }^{3}$

2 Alexandre de Moraes, Constituição do Brasil interpretada, 2002, Atlas, p. 224.

3 TRF-2 ${ }^{a}$ Região, Rel. Des. Paulo Espírito Santo, Inquérito n 167, Processo 2002.02.01.037248-2,

$2^{a}$ Seção, DJ de 28.3.2003, p. 386. 
A denunciação caluniosa é crime reprimido pelo art. 339, do Código Penal e combinado com o art. 648, do CPP dá azo ao trancamento de inquéritos ou processos penais natimortos, sem justo motivo:

“Art. 339. Dar causa à instauração de investigação policial, de processo judicial, instauração de investigação administrativa, inquérito civil ou ação de improbidade administrativa contra alguém, imputando-lhe crime de que o sabe inocente:

Pena - reclusão, de dois a oito anos, e multa."

“Art. 648. A coação considerar-se-á ilegal:

I - quando não houver justa causa."

A falta de justa causa afasta a figura do possível delito, tendo em vista a ausência do ato ilícito. O STF vem retirando do Ministério Público o poder de instaurar inquérito policial sem um mínimo de plausibilidade ou de justo motivo, trancando-o:

"Habeas Corpus. Inquérito policial instaurado pelo fato de vereadores terem recebido importâncias em virtude de lei municipal que veio a ser considerada inconstitucional pelo Tribunal de Contas do Estado, conhecimento parcial, com base na letra d do inciso i do artigo 102 da Constituição, já que, no caso, não há sequer conexão determinadora do deslocamento da competência. Sendo o fato que deu margem à instauração do inquérito policial manifestadamente atípico, é de trancar-se esse inquérito por falta de justa causa. Habeas Corpus conhecido quanto ao paciente que atualmente é deputado federal, e deferido com relação a ele." 4

“(...) Ausência de tipicidade penal - Falta de justa causa - Trancamento de IPM - Pedido deferido. O trancamento do inquérito policial pode ser excepcionalmente determinado em sede de habeas corpus, quando flagrante - em razão da atipicidade da conduta atribuída ao paciente - - a ausência de justa causa para a instauração da persecutio criminis. Nos delitos de calúnia, difamação e injúria, não se pode prescindir, para efeito de seu formal reconhecimento, da vontade deliberada e positiva do agente de vulnerar a honra alheia. Doutrina e jurisprudência. Não há crime contra a honra, se o discurso contumelioso do agente, motivado por um estado de justa indignação, traduz-se em expressões, ainda que veementes, pronunciadas em momento de exaltação emocional ou proferidas no calor de uma discussão. Precedentes." 5

4 STF, Rel. Min. Moreira Alves, $1^{\mathrm{a}}$ T., HC $\mathrm{n}^{\circ}$. 67.039/RS, DJ de 24.11.89.

5 STF, Rel. Min. Celso de Mello, HC n. 71.466/DF, DJ de 19/12/94. 
Por fim, em respeito ao mandamento da inviolabilidade da honra e da imagem do agente público, só deverá ser proposta ação de improbidade administrativa quando haja fundamento ou indícios razoáveis da prática de um ato de improbidade, sem que ele decorra da imaginação ou da criação intelectual do subscritor da respectiva lide.

\section{II - Abuso do Ministério Público ou do órgão público do direito de acionar}

O controle que o Ministério Público exerce sobre toda a coletividade é necessário para garantir a manutenção da democracia e do Estado de Direito que reina em nosso país.

Triste seria uma sociedade que não tivesse no MP a devida "blindagem" contra abusos e violências perpetradas pelo Poder Público.

Não se questiona o brilho dos notáveis componentes do parquet, pois é justamente neles que toda a população deposita confiança no combate à corrupção e na imoralidade que mancha a nação.

O Brasil é um país rico e agraciado no campo dos valores humanos. Sucede que, como todo país em via de desenvolvimento, a corrupção assola nosso sistema público, onde figuras nefastas enlameiam suas funções com negociatas e derramamento de dinheiro público, pago pelos sofridos contribuintes, combalidos pelo crescente aumento da carga tributária.

De nada adiantam os aumentos de impostos ou as reformas estruturais se não houver um arrocho na corrupção e no desperdício do dinheiro público.

Estes fatos são notórios e não necessitam de muitas linhas para convencer o leitor de que um dos grandes males do Brasil é a corrupção pública.

Ocorre que não podem ser generalizados todos os atos públicos tidos como ilegais, como se eles fossem ímprobos. Nem que todos os agentes públicos são imorais e devassos.

A prudência é necessária para conferir uma dose de temperamento no direito de acionar, pois a ninguém é dado o direito de utilizar a via da ação de improbidade administrativa para atingir o homem público, sem que estejam presentes indícios ou justificações concretas e sérias, obtidas por meio lícitos, não decorrendo da criação intelectual de quem quer que seja.

Verificadas muitas injustiças, com o manejamento de ações de improbidade administrativa natimortas, sem nenhuma possibilidade jurídica, o legislador baixou fórmula que interdita a humilhação do homem público de bem, tendo em vista que o art. 17 e seus $\S \S 6^{\circ}, 7^{\circ}, 8^{\circ}, 9^{\circ}, 10$ e 11 foram construídos para curar chagas de injustiças, verificadas com a utilização indevida de ações insubsistentes, com falsa ou precária motivação de improbidade administrativa.

A partir do momento que o acesso ao judiciário é uma garantia fundamental. que nem a lei pode excluir o direito à tutela jurisdicional (art. $5^{\circ}, \mathrm{XXXV}$, da $\mathrm{CF}$ ), o Estado-Juiz, sempre que procurado não poderá se furtar de sua indelegável missão de fazer justiça. Sendo chamado a exercer sua jurisdição, aplicando o direito ao caso 
concreto, o judiciário verifica as condições da ação e emite um juízo de valor sobre o caso colocado em seu raio de responsabilidade.

Na prática, com uma atuação viril, o Ministério Púbico vem multiplicando o ingresso de ações civis públicas, aí abrangidas as ações de improbidade administrativa, muitas delas sem substância de sustentação, levando Rogério Lauria Tucci, com apoio em Kazuo Watanabe, a identificar que elas representam "autêntica panacéia geral para toda e qualquer situação":

"Realmente, as diversificadas atuações dos membros do parquet, tanto no plano federal, como no estadual, chegando a formular pedidos juridicamente impossíveis, a substituir, sem legitimidade, entidades de classe, e a agir sem o imprescindível interesse processual, têm, segundo entendemos, extravasado, consideravelmente, os lindes estabelecidos na legislação em vigor, de sorte a tornar a ação em estudo inadequada ao escopo perseguido pelo demandante" 6

Assim, nasce o abuso de direito do Ministério Público, quando propõe ações natimortas, em que inexiste o ato de improbidade administrativa, sendo improcedente por falta de tipicidade da conduta do agente público ou até mesmo pela inadequação da via eleita ( $\$ 8^{\circ}$ do art. 17 da Lei $n^{\circ} 8.429 / 92$ ).

Essa proliferação de ações ilegítimas não se encerra rapidamente, pois nosso sistema processual é extremamente perverso, com uma tramitação lenta, parece concebido para que o processo não termine, sangrando o réu da ação quase até a morte, pois a simples propositura de tão grave ação de improbidade administrativa é um ultraje para quem não deu azo ao seu enquadramento.

O princípio da economia processual evita a exposição desnecessária das partes, satisfazendo o ideal de justiça.

Inocorrendo ato de improbidade administrativa, o Juiz deve extinguir a ação:

“Agravo de instrumento. Ação civil pública. Improbidade administrativa formal. Circulares que operam numa faixa de generalidade e abstração. Inexistência de ato concreto que importe violação dos princípios administrativos que informam a administração pública. Inteligência do art. 11, I, da Lei $n^{\circ} 8.429 / 92$. Critério da impessoalidade, previsto constitucionalmente como princípio da administração pública, uma faceta do princípio da isonomia, não abalado. Ausência do interesse de agir reconhecida em sede de agravo. Possibilidade. Extinção da ação na origem. Solução proposta $e x$ officio que evita a exposição desnecessária das partes, atende ao princípio da economia processual e satisfaz ao ideal de justiça." 7

6 Rogério Lauria Tucci, “Ação civil pública: abusiva utilização pelo Ministério Público e distorção pelo Poder Judiciário", in Aspectos polêmicos da ação civil pública, Saraiva, 2003, p. 456.

7 TJ/SC, Des. César Abreu, AI n 2001.013380-6, 3ª Câmara de Direito Público, julgado em 25.04.2003. 
O Ministro Sálvio de Figueiredo Teixeira lembrou que "o processo não é um jogo de esperteza, mas instrumento ético da jurisdição para efetivação dos direitos de cidadania". ${ }^{8}$

O STF, pela voz do Ministro Celso de Mello, acentuou: "O ordenamento jurídico brasileiro repele práticas incompatíveis com o postulado ético-jurídico de lealdade processual. $O$ processo não pode ser manipulado para viabilizar abuso de direito, pois essa é uma idéia que se revela frontalmente contrária ao dever de probidade que se impõe à observância das partes. O litigante de má-fé - trata-se de parte pública ou de parte privada - deve ter a sua conduta sumariamente repelida pela atuação jurisdicional dos juízos e dos tribunais, que não podem tolerar o abuso processual como prática descaracterizadora da essência ética do processo." 9

Não obstante a morosidade do Judiciário, o abuso do direito de acionar do MP é verificado quando ele extrapola os limites de um direito em prejuízo de quem é colocado no pólo passivo da ação.

Nas precisas palavras do Des. Rui Stoco, em sede doutrinária, "o direito cessa onde o abuso começa". ${ }^{10}$

Assim, o exercicio da prerrogativa de acionar encontra limites na esfera jurídica alheia que veda a utilização anormal de direitos.

Caio Mário da Silva Pereira," sintetiza o sentido da expressão "abuso de direito":

“Abusa, pois, de seu direito o titular que dele se utiliza levando um malefício a outrem, inspirado na intenção de fazer mal e com proveito próprio. $O$ fundamento ético da teoria pode, pois, assentar em que a lei não deve permitir que alguém se sirva de seu direito exclusivamente para causar dano a outrem."

Rui Stoco ${ }^{12}$ também tece importantes considerações sobre o tema:

"Também se comporta o abuso na intenção ou no animus nocendi, quando o agente se inspira na intenção de causar mal a outrem (...). Do que se conclui que $o$ indivíduo para exercitar 0 direito que the foi outorgado ou posto à disposição deve conter-se dentro de uma limitação ética, além da qual desborda do lícito para o ilícito e do exercício regular para o exercício abusivo.

Como se impõe a noção de que nosso direito termina onde se inicia o direito do próximo, confirma-se a necessidade de prevalência da teoria da relativi-

8 STJ, Rel. Min. Sálvio de Figueiredo Teixeira, Resp. $n^{\circ} 65.906,4^{\star}$ T;, DJ de 02.03.98, p. 93.

9 STF, Rel. Min. Celso de Mello, Ed. 246.564-0, 2 T., julgado em 19.10.99, RTJ 270/72.

10 Rui Stoco, Abuso do direito e má-fé processual, RT, 2002, p. 57.

11 Caio Mário da Silva Pereira, Instituiçð̄es de Direito Civil, vol. 1, 18' ed., Forense, 1995, p. 430.

12 Rui Stoco, cit. ant., p. 58. 
dade dos direitos subjetivos, impondo-se fazer uso dessa prerrogativa apenas para satisfação de interesse próprio ou defesa de prerrogativa que the foi assegurada e não com o objetivo único de obter vantagem indevida ou de prejudicar outrem, através da simulação, da fraude ou da má-fé.

Para situar-se no campo da normalidade e da licitude não basta estar legitimado pela legislação existente e asseguradora de direito.

Impõe-se fazer uso adequado do arsenal legislativo existente e não dele prevalecer e utilizá-lo para fim ilícito ou pretensão subalterna.

Pode-se usar a lei permissiva em vigor, de forma aparentemente adequada para obter fim ilegítimo ou não permitido pelo consenso nacional, hipótese em que se irá detectar o abuso no exercício do direito".

Irineu Strenger conceitua abuso de direito: ${ }^{13}$

"Abuso de direito é o ato realizado, com apoio em preceito legal, que causa dano a interesse não especificamente protegido pelo ordenamento positivo, manifestado pela lesão a princípios éticos e sociais, objetiva ou subjetivamente, mediante adequação entre o intencional e o sentido da lei."

O abuso do poder, no campo do direito administrativo, é espécie do gênero do abuso do direito.

In casu, abusa do direito quem ajuíza a ação com o rótulo de proteger a probidade administrativa e esquarteja o direito do agente público em ser acionado se não cometer ato de devassidåo, com má-fé ou interesse espúrio, visando lesar o erário público.

Como fiscal da lei, o MP possui a missão indelegável de proteger o interesse legítimo, mesmo que ele represente uma oposição aos entes de direito público.

A sua responsabilidade perante a sociedade não se dissolve quando o MP é autor de denúncia ${ }^{14}$ ou de ação de improbidade administrativa. Pelo contrário, aumenta o peso da responsabilidade, tendo em vista que o MP possui na denúncia os elementos que foram colhidos no inquérito policial sem o crivo do contraditório.

$\mathrm{Na}$ via da ação de improbidade administrativa, existe a figura do inquérito civil público, bem como a sindicância que antecede o processo disciplinar. Todos estes instrumentos legais servem como ferramentas para o MP aquinhoar dados e fatos e arquivar os casos em que não existem provas ou indícios contra os acusados, acionando aqueles que realmente restarem provados.

13 Irineu Strenger, Reparação do dano internacional privado, RT, 1973, p. 24.

14 "A denúncia deve necessariamente apresentar-se lastreada em elementos que evidenciam a viabilidade da acusação, sem que se configure abuso do poder de denunciar, coarctável por meio de habeas corpus." (STJ, RSTJ 37/104.) 
Por isso é que combatemos veementemente os procedimentos genéricos ${ }^{15}$, instaurados sem elementos de indícios, mas com a direção certeira de tentar encontrar alguma ou suposta falta funcional.

Acusação genérica ${ }^{16}$ possui o esteio de configurar o abuso do direito de acionar, pois é defeso tal procedimento, que exige um mínimo de indício da existência de um fato reprimido pelo ordenamento jurídico.

Pensa igual Adilson Abreu Dallari, ${ }^{17}$ que discorre sobre a ilegalidade cometida pela Administração Pública e pelo Ministério Público quando eles baixam procedimentos genéricos, visando encontrar algo contra o agente público:

"Fazendo uma comparação, no campo do direito administrativo, pode-se dizer que o inquérito civil está para a ação civil pública, assim como a sindicância está para o processo administrativo. Não é possível instaurar-se um processo administrativo disciplinar genérico para que no seu curso se apure se eventualmente alguém cometeu alguma falta funcional.

Não é dado à Administração Pública, nem ao Ministério Público, simplesmente molestar gratuidade e imotivadamente qualquer cidadão por alguma suposta eventual infração da qual ele talvez tenha participado.

Vale também aqui o princípio da proporcionalidade inerente ao poder de polícia, segundo o qual só é legítimo o constrangimento absolutamente necessário e na medida do necessário."

A seguir, o citado mestre arremata: ${ }^{18}$

“Repugna a consciência jurídica aceitar que alguém possa ser constrangido a figurar como réu numa ação civil pública perfeitamente evitável. Configura abuso de poder a propositura de ação civil temerária, despropositada, não precedida de cuidados mínimos quanto à sua viabilidade.

15 Aprofundado em "Necessidade de justa causa para a instauração de processo administrativo disciplinar. Impossibilidade do procedimento genérico para que no seu curso se apure se houve ou não falta funcional", Mauro Roberto Gomes de Mattos, in Revista lbero-Americana de Direito Público, vol. IX, Ed. América Jurídica, 2003, p. 175.

16 “(...) Ação penal. Trancamento. Denúncia inepta. A denúncia deve conter a narração do fato criminoso, com todas as suas circunstâncias (CPP, art. 41), com precisa indicação da conduta impetrada ao réu, de modo a propiciar-lhe o pleno exercício do direito de defesa. É inepta a denúncia que formula acusação genérica ou que não aponta de modo circunstanciado qual o fato punível cuja autoria é imputada ao réu (...) (STJ, RSTJ 134/519.)

"É inepta a queixa-crime que, por meio de acusação genérica, imputa aos diretores de uma empresa um fato penalmente atípico." (STJ, RSTJ, 116/392.)

17 Adilson de Abreu Dallari, "Limitação do Ministério Público na ação civil pública", in Improbidade administrativa - questóes polêmicas e atuais, Malheiros, 2001, p. 38.

18 Adilson de Abreu Dallari, cit. ant., p. 38. 
A realização ou não do inquérito civil, como providência preliminar à promoção da ação civil pública, pode ser um importantíssimo indicador do nível de correção da conduta do agente do Ministério Público, da sua maior ou menor diligência no exercício de suas funções.

A experiência prática tem revelado a ocorrência desagradavelmente freqüente de ações civis públicas totalmente despropositadas, que poderiam ter sido perfeitamente evitadas se o promotor público tivesse tido a mais mínima e elementar das cautelas, que é simplesmente ouvir o suposto infrator."

Essa atuação abusiva frente à ação de improbidade administrativa permite tanto ao Tribunal ad quem, como ao juiz singular com base no $\S 10$ do art. 17 da LIA, tranque a temerária ação, em qualquer fase do processo, quando reconhecida a inadequação da ação de improbidade, extinguindo a lide sem julgamento de mérito (§ 11 do art. 17).

O direito repudia o seu exercício abusivo, não bastando o MP ingressar com a ação de improbidade administrativa e defender com isto o seu interesse ativo de propor tal pleito. E nem tampouco impressiona o argumento de que o indeferimento da inicial cerceia-lhe a sua ampla atuação, pois o abuso de direito é verificado quando inexiste na ação de improbidade prova de ilicitude ou improcedência ou a via é inadequada.

Nestas situações o órgão do MP estará desautorizado a invadir a intimidade e a honra de quem quer que seja.

Não existe um superpoder que possa atuar acima do bem e do mal, como dito pelo Min. Celso de Mello, nas entrelinhas do voto no $\mathrm{MS} \mathrm{n}^{\circ} 23.452 / \mathrm{RJ}$ :

“Não há, no sistema constitucional brasileiro, direitos ou garantias que se revestem de caráter absoluto, mesmo porque razões de relevante interesse público ou exigências derivadas do princípio de convivência das liberdades legitimam, ainda que excepcionalmente, a adoção por parte dos órgãos estatais de medidas restritivas das prerrogativas individuais ou coletivas, desde que respeitados os termos estabelecidos pela própria Constituição.

O estatuto constitucional das liberdades públicas, ao delinear o regime jurídico a que estas estão sujeitas - e considerado o substrato ético que as informa - permite que sobre elas incidam limitações de ordem jurídica, destinadas, de um lado, a proteger a integridade do interesse social e, de outro, a assegurar a coexistência harmoniosa das liberdades, pois nenhum direito ou garantia pode ser exercido em detrimento da ordem pública ou com desrespeito aos direitos e garantia de terceiros." 19

19 STF, Rel. Min. Celso de Mello, MS n²3.452/RJ, pleno, DJ de 12.5.2000. 
Muito embora o direito de o MP acionar seja considerado direito público subjetivo autônomo e abstrato, incumbindo-lhe a defesa da ordem jurídica, dentre outras, a lei pode estabelecer condições necessárias ao seu exercício, como forma de evitar abusos de direito, com a propositura de lides inúteis, em que o pedido já nasce contaminado pela sua insubsistência. ${ }^{20}$

Nesse formato, dispõem o Código de Processo Civil (art. 267, VI) ${ }^{21}$ e o Código de Processo Penal (art. 43) ${ }^{22}$, em homenagem ao interesse público que quando não concorrer qualquer das condições da ação seu exercício é vedado.

Assim, a Lei Processual adotou a teoria da substanciação, na qual é consagrado que não basta o autor afirmar a existência da relação jurídica, sendo também necessária a demonstração do fato concreto que deu azo à sua pretensão:

"A atividade jurisdicional, destinando-se a compor as lides, será exercida quanto a uma concreta relação jurídica, identificável por seus sujeitos e pelas coordenadas de tempo e lugar. O Juiz não emite comandos genéricos e indeterminados, tarefa esta própria do legislador. Extingue-se, sem julgamento do mérito, o processo cuja inicial limita-se a pleitear o reconhecimento de uma tese jurf́dica". ${ }^{23}$

Mantendo eficaz a teoria da substanciação, dispõe o art. 295, parágrafo único, II, do CPC, que a petição inicial será indeferida "quando da narração dos fatos não decorrer logicamente a conclusão".

O TJ/SC, na Ap. Cível n ${ }^{\circ}$ 2001.008770-7, Rel. Des. Newton Trisotto, prestigiou a teoria da substanciação em ação popular, extinguindo a lide por falta de plausibilidade jurídica:

"Ação popular. Convênio entre Estado de Santa Catarina e instituição de ensino. Dispensa de licitação. Petição inicial. Teoria da substanciação. Imprescindibilidade da descrição dos atos lesivos ao erário ou atentatórios à moralidade pública. Extinção do processo. Em princípio, não pode ser extinto o processo, in limine, por fundamento relacionado com o mérito da causa. No entanto, em direito não há lugar para absolutos (Teori Albino Zavascki). Presta-se a ação popular para o cidadão pleitear a anulação de

20 “Alegação manifestadamente infundada, porque desarrazoada e contrária ao sistema juridico e à jurisprudência firme, inclusive do Superior Tribunal de Justiça, denota litigante de má-fé, a justificar, mesmo de ofício, a multa autorizada em lei" (STJ, Rel. Min. Sálvio de Figueiredo Teixeira, Resp $n^{0} 270.232,4^{\star}$ T., julgado em 5.10.2000.)

21 “Art. 267. Extingue-se o processo, sem julgamento do mérito: (...) VI - quando não concorrer qualquer das condiçð̌es da ação, como a possibilidade jurídica, a legitimidade das partes e o interesse processual (...)"

22 "Art. 43. A denúncia ou queixa será rejeitada quando: (...) III - for manifesta a ilegitimidade da parte ou faltar condição exigida pela lei para o exercício da ação penal".

33 TFR, Rel. Min. Eduardo Ribeiro, AC n 157.480-CE, 6^ T., DJU de 19.04.89, p. 5.776. 
atos lesivos ao patrimônio público, no seu conceito mais amplo (Lei $\mathrm{n}^{\circ}$ $4.717 / 65$, art. $1^{\circ}$ ). Nela, o autor não visa à satisfação de um interesse individual; litiga como substituto processual da coletividade, na defesa de seus interesses. Se os fatos descritos na petição inicial revelam que $O$ ato impugnado não é contrário à lei ou à moralidade administrativa, faltando, por isso, plausibilidade jurídica ao pleito, a sociedade destinatária da proteção legal não pode ser punida tendo que suportar os custos do processo que, nessa hipótese, pode ser julgado extinto liminarmente."

Ou pelas palavras de Luiz Wanderley Gazoto: ${ }^{24}$

"Mas o que nos interessa no momento é que a revelação da causa de pedir permite ao Juiz realizar o cotejo entre os fatos e os fundamentos jurídicos do pedido e concluir se, realmente, o direito alberga a pretensão do autor, constatando a razoabilidade do exercício do direito de ação, tudo isso deixa patenteado que o exercício do direito de ação não é arbitrário, desvinculado da realidade concreta ou de fato que justifique o seu emprego, mas deve estar subordinado à existência do interesse legítimo e finalístico, manifestado na necessidade e na utilidade do provimento judicial."

É dever do Estado ${ }^{25}$ zelar pela lealdade processual, não sendo permitido o ingresso de lide temerária.

Posta a situação em foco, extrai-se que o poder de acionar possui temperamentos, ele não é absoluto mesmo que ancorado na defesa do patrimônio público, do patrimônio social, do meio ambiente, do consumidor e dos bens e demais direitos que lhe são afetos, "precisa ser entendida e compreendida nos seus justos limites" ${ }^{26}$

Seguindo as radiações do CPC e do CPP, a Lei de Improbidade Administrativa permitiu que pelo $\S 11$, do art. 17, em qualquer fase do processo, reconhecida a inadequação da ação de improbidade administrativa, o Juiz extinguirá a ação.

Comprovando a necessidade da respectiva alteração legislativa, contida nos $\S \S$ $6^{\circ}$ "usque" 11 , do art. 17, da LIA, várias açōes de improbidade temerária, se arrastaram durante muitos anos, para serem sepultadas nos tribunais superiores, após o julgamento das competentes apelaçðes cíveis, depois de alguns anos da sua propositura.

24 Luiz Wanderley Gazoto, $O$ principio da não-obrigatoriedade da ação penal pública, Ed. Manole, 2003, p. 132/133.

25 "É dever do Estado zelar pela lealdade processual, cabendo ao juiz, de ofício, aplicar a sanção cabível. Recurso não conhecido." (STJ, Rel. Min. Ruy Rosado de Aguiar, Resp nº 51.208, 4 T., DJ de 12.6.95., p. 17.628.)

26 TJ/SP, 4' CC, RTJESP 117/42, apud Rogério Lauria Tucci, Ação civil pública: abusiva utilização pelo Ministério Público e distorçāo pelo Poder Judiciário, cit. ant., p. 356. 
Irregularidades, meramente formais assaz de vezes confundidas pelo MP como atos de improbidade administrativa, são descartadas pelo Judiciário:

"Ação civil pública. Improbidade administrativa. Irregularidades meramente formais, restando descartada a configuração de atos de improbidade. Recurso não provido." 27

Vislumbrando abuso de direito de acionar, onde inexistia documento comum e próprio, o TJ/SP descartou medida cautelar proposta pelo MP, sob os seguintes argumentos constantes na ementa do v. aresto:

"Medida cautelar. Rotulada de exibição de documentos. Existência de documento comum e próprio. Denominação errada. Irrelevância. Pretensão à quebra de sigilo bancário. Fase investigatória em procedimento administrativo. Pedido jurisdicionalizado. Legitimidade ad causam do investigado e legitimidade ad causam da instituição financeira. Inexistência de fato jurídico determinado. Abuso de direito. Medida desacolhida. Recurso não provido. A pretensão do Ministério Público volta-se à quebra do sigilo bancário da pessoa que está sendo investigada em inquérito civil pela prática de ato de improbidade administrativa, optando pela jurisdicionalização do pedido, de modo que não é o banco o sujeito passivo da relação jurídica processual, mas o investigado. A medida cautelar de exibição de documentos pressupõe a existência de documento próprio e comum, o que não é o caso, mas a errada denominação da ação não prejudica o pedido, posto não ser requisito essencial da inicial. Não havendo um fato jurídico determinado imputado ao investigado, constitui abuso de direito pretender levantar o sigilo dos negócios bancários que realizou, não podendo ser acolhido o pedido nesse sentido formulado". ${ }^{28}$

Na mesma esteira, o MP tentou quebrar sigilo bancário de delegado de polícia, por ter recebido denúncias anônimas de prática de improbidade administrativa, sendo declarada também medida abusiva:

"Medida cautelar. Mérito. Exibição de documentos. Pedido que objetiva a quebra de sigilo bancário de autoridade policial (delegado de polícia), que está sendo investigada em inquérito civil em decorrência de denúncias anônimas de prática de improbidade administrativa. Ação procedente. Inadmissibilidade. Inexistência de fato jurídico determinado que autorize a in-

27 TJ/SP, Rel. Des. Clímaco de Godoy, Ap. Cível n 91.277-5/SP, $4^{a}$ Câmara de Direito Público, DJ de 26.08.99.

28 TJ/SP, Rel. Des. Ruiter Oliva, Ap. Cível no 47.296-4/Santos, $9^{\mathbf{a}}$ Câmara de Direito Privado, DJ de 25.08.98. 
vestigação; pretensão que se constitui em efetiva medida abusiva e contrária aos direitos individuais do investigado. Recurso improvido." 29

Configurada, em qualquer fase do processo, a inadequação da ação de improbidade, o Juiz extinguirá a ação sem julgamento do mérito, na forma do §11, do art. 17, para evitar o abuso do direito de acionar do MP ou da Administração Pública:

"Agravo regimental. Ação civil de improbidade administrativa. Em qualquer fase do processo, reconhecida a inadequação da ação de improbidade, o Juiz o extinguirá sem julgamento do mérito. Art. 17, § 11, da Lei ${ }^{\circ} 8.429 / 92$. Possibilidade de o juízo rejeitar parcialmente a inicial, em momento superveniente ao seu recebimento integral, excluindo determinadas causas de pedir, não aptas a deflagrar o prosseguimento da ação. Decisão mantida. Agravo regimental desprovido." 30

Conclui-se, esperando que o MP e a Administração Pública não ingressem com ações de improbidade administrativa inadequadas, pois a parte passiva tem o direito de não ser acionada de maneira aleatória.

Exige-se justa causa para o ajuizamento da ação de improbidade administrativa, consubstanciada em indícios e justificações robustas, com a possibilidade do pedido vislumbrando-a, mesmo que em tese.

O $§ 11$ em questão funciona como forma de evitar-se o abuso de poder de acionar, aniquilando a ação insubsistente e desarrazoada.

A ação aventureira ou temerária não encontra espaço em nosso ordenamento jurídico:

"Só há abuso de direito quando alguém ingressa em juízo sem motivo legítimo, de má-fé que por erro tão ostensivo e leviandade tão manifesta que só o espírito aventureiro ou a temeridade poderia explicar." 31

Nesses termos, a ação deflagrada nasce morta, na medida em que objetiva reprimir e punir um ato vazio em efeitos.

Aliás, falta de interesse de agir pode ser reconhecida ex officio em qualquer grau de jurisdição, sem que haja preclusão (RSTJ 54/129), tanto na fase recursal (JTA 112/62), como até mesmo em recurso especial (RTJ 110/127):

"Ação civil pública. Improbidade administrativa. Inexistência de comprovação de lesão ao patrimônio público. Insucesso da ação. Inexistindo de-

29 TJ/SP, Rel. Des. Silva Rico, Ap. Cível nº 76.743-4/Santos, $9^{a}$ Câmara de Direito Privado, DJ de 27.04.99.

30 TJ/RS, Rel ${ }^{\mathbf{a}}$. Des ${ }^{\mathbf{a}}$. Rejane Maria Dias de Castro Bins, Ag. Regimental n $70006690853,22^{\mathrm{a}} \mathrm{CC}^{\circ}$, DJ de 19.08.2003.

31 TJ/SP, Rel. Des. Felizardo Cali, Ap. Cível n 169.791, RJTJSP 9/53. 
monstração de que ocorreu lesão ao patrimônio público, por ação ou omissão, dolosa ou culposa do agente, impõe-se o insucesso da ação civil pública fundada em ato de improbidade administrativa." 32

"Ação civil pública. Improbidade. Não caracterização dos fatos. Improcedência. Se não existem dados concretos, completos e a convencer da existência dos atos de improbidade denunciados pelo Ministério Público, moldados em ação/omissão do réu/apelado com tais requisitos e caracterização que levem à responsabilização pretendida, é improcedente a ação. $O$ exercício da ação civil é estimulado pela própria lei que, assim, libera o seu autor dos ônus decorrentes de uma eventual sucumbência, à exceção da hipótese de se evidenciar litigância temerária com má-fé ou dolo, cuja ocorrência, entretanto, não se presume e nem decorre da simples improcedência da referida ação; deve ser concretamente demonstrado e devidamente caracterizado o dano processual ou à parte." ${ }^{33}$

Funciona o § 11, do art. 17, da LIA, como uma ferramenta colocada à disposição da sociedade para não ser molestada injustamente por uma ação de improbidade sem base de sustentação ou elementos de conviç̧̃̃o.

O direito de acionar é constitucional, encontrando, contudo, limites no direito alheio, visto que são suprimidos abusos ou excessos deste direito.

Não existindo ato de improbidade, nem em tese, enterra-se a possibilidade jurídica de acionar-se agente público que não cometeu ato ímprobo.

Portanto, abusa do direito de acionar aquele que propõe ação de improbidade natimorta, sem substância ou base de sustentação.

\section{III - Da responsabilidade civil do açodado denunciante}

Como bem averba Betina Rizzato Lara, "o tema da responsabilidade civil tem hoje lugar privilegiado em todos os ramos do direito, não podendo deixar de ter destaque, igualmente, no direito processual civil". ${ }^{34}$

Por esta razão, o $\S 6^{\circ}$, do art. 37 , da CF, estipula que as pessoas jurídicas de direito público responderão objetivamente pelos danos que seus agentes, nessa qualidade, causarem a terceiros.

$O$ direito do ente público de utilização da faculdade de acionar por ato de improbidade não deve ser irresponsável. Ou, como deixamos grafado anteriormente em nosso "Limite da Improbidade Administrativa - $\mathrm{O}$ direito dos Administrados dentro da Lei n 8.429/92":

32 TJ/MG, Rel. Des. Hyparco Immesi, Ap. Cível n 000.266.045-4/00, 4 CC, DJ de 19.9.2003.

33 TJ/MG, Rel. Des. Geraldo Augusto, AP. Cível n 000.296.143-1/00, $1^{\circ} \mathrm{CC}$, DJ de 7.2.2003.

34 Betina Rizzato Lara, Liminares no Processo Civil, 2" ed., RT, 1994, p. 76. 
"A denúncia irresponsável motivada por ingredientes políticos ou causas que não são jurídicas é abominada pelo direito, por invadir a privacidade do acusado sem elementos para tal.

Assim, uma lei tão severa, possuindo penas graves, como a de improbidade, não pode ser direcionada de forma irresponsável, pois ela foi criada para aniquilar o agente público mau-caráter, que rompe a probidade para atingir fins ilícitos." 35

E coube ao art. 19, parágrafo único, da Lei de Improbidade Administrativa, punir o açodado denunciante (autor da ação) no pagamento pelos danos materiais, morais ou à imagem que houver provocado ao agente público injustamente.

Sucede que tal cânone legal fica restrito ao caput do art. 19 da citada lei, que somente pune os denunciantes pelo crime de denunciação caluniosa, devendo o ofendido provar que $o$ autor da ação sabia que ele era inocente.

Esta é a uma prova quase que impossível, pois a demonstração de um elemento tão subjetivo, que está guarnecido na vontade do interlocutor que subscreve a exordial de improbidade, é muito diff́cil.

Vou mais além, pois a matriz da responsabilidade civil é constitucional (art. 37, $\S 6^{\circ}$, da CF), sendo defeso a sua aplicação somente aos casos de denunciação caluniosa, por parte do ente de direito público. Basta haver o constrangimento, com a indevida exposição no pólo passivo da ação de improbidade administrativa, que 0 agente público honesto já se condenou por estar alçado a condição de Réu. Pouco importa para ele, homem de bem, que, a posteriori a decisão judicial the seja favorável, tendo em vista que ele já se automutilou psiquicamente, enquanto durou a natimorta ação judicial.

Este grave e irresponsável dano moral merece severa reprimenda, pois a responsabilidade do poder público é objetiva.

Adilson Abreu Dallari, sensibilizado com esse constrangimento do agente público que não deu causa às suspeitas infundadas do comentimento de um ato de improbidade administrativa, anota:

"E um constrangimento, de qualquer maneira, para qualquer pessoa, ser processado. Uma autoridade pública, quando é processada, tem um desgaste muito maior que qualquer cidadão, porque o simples fato de ser processado tem grande repercussão política, afeta seriamente a vida pública da pessoa. Esse risco, bastante concreto, desestimula gente decente, honesta, correta, a ousar trabalhar na Administração Pública. É oportuno lembrar que qualquer agente público, e especialmente que recebeu da ordem jurídica, da coletividade, em eleições livres, a confiança para tomar decisões em nome

35 Mauro Roberto Gomes de Mattos, $O$ Limite da Improbidade Administrativa - $O$ direito dos administrados dentro da Lei n 8.429/92, Ed. América Jurfdica, 2004, p. 568. 
da coletividade, merece o mínimo de respeito, merece ter respeitado o 'mais mínimo', o mais elementar dos direitos, que é o de ser ouvido." ${ }^{36}$

A responsabilidade civil pela indevida propositura de ação de improbidade é objetiva, não ficando limitada somente aos casos em que o autor da ação sabe que os Réus são inocentes (art. 19, da Lei de Improbidade Administrativa). Basta o nexo causal entre a indevida ação de improbidade e o dano moral causado ao agente público ou ao terceiro, que ostentem a incômoda posição no pólo passivo da lide, para fazer nascer a responsabilidade civil. Ou seja, após o decurso do tempo, onde o agente público ou o terceiro foram acusados de grave ato de improbidade, com a indevida exposição pública, com constrição de bens ou não, faz nascer a lesão de ordem moral e material, tendo em vista que a futura absolvição demonstra que o manejo da ação foi temerário.

O ritual que antecede a ação de improbidade (sindicância, inquérito civil público, processo administrativo disciplinar ou outro meio legal de investigação) deve demonstrar, de forma inequívoca, elementos de base sólida de acusação, como dito alhures.

A prudência e a cautela são elementos essenciais na atuação pública, quando determinados atos podem causar danos às pessoas e a seus familiares, tendo em vista que quando se combate ou investiga atos de improbidade administrativa, somente poderá ser acionado aquele que cometeu ato ilícito previsto pela aludida lei, não existindo discricionarismo do órgão acusador, porque a lei fixa critérios objetivos para o respectivo enquadramento.

A indenização a que o denunciante irresponsável está compelido, por dano material ou moral, possui o efeito pedagógico punitivo para frear a onda de "denuncismo" infundado, e compensatório para a vítima, que terá no dinheiro a diminuição do ferimento da sua honra objetiva e subjetiva.

Portanto, o dano moral nasce quando alguém lesiona o direito da personalidade, que é a intimidade, imagem, bom nome, privacidade, integridade, reputação, etc.

Assim, havendo dano material, moral ou à imagem da vítima, o agente público agressor será compelido a pagar pelo seu ilícito.

O dano material não é presumível, terá que ser provado pelo agente público atingido. Já o dano moral é implícito, tendo o seu nascimento na própria ofensa.

Fica invencivelmente demonstrado o dano moral pela humilhação e tristeza com que foi acometido o agente público, indevidamente alçado à condição de acusado, com reflexo no âmbito das relações familiares, sociais e profissionais, respingando na reputação, no bom nome, e na imagem da vítima perante terceiros.

Quem exerce uma jurisdição temerária causa prejuízo à estrutura do Judiciário e à parte que é inocentada de uma injusta imputação.

Nas hipóteses em que o autor da ação de improbidade administrativa liminarmente indisponibiliza os bens dos acusados ou consegue o afastamento provisório

36 Adilson Abreu Dallari, "Limitações à atuação do Ministério Público na Ação Civil Pública", in Improbidade Administrativa - Questões polêmicas e Atuais, Malheiros, 2001, p. 35 
do agente público, em havendo reversibilidade da medida, com o julgamento improcedente da ação, nasce também o direito de indenizar.

Essa é a dicção do art. 811 do CPC:

“Art. 811 - Sem prejuízo do disposto no art. 16, o requerente do procedimento cautelar responde ao requerido pelo prejuízo que lhe causar a execução da medida:

I - se a sentença no processo principal lhe for desfavorável;

II - se obtida liminarmente a medida no caso do art. 804 deste Código, não promover a citação do requerido dentro de 5 (cinco) dias;

III - se ocorrer a cessação da eficácia da medida, em qualquer dos casos previstos no art. 808 deste Código;

IV - se o juiz acolher, no procedimento cautelar, a alegação de decadência ou prescrição do direito do autor (art. 810)."

Mesmo que não exista a má-fé na conduta do autor da ação de improbidade administrativa, ele deverá responder pelo fato objetivo do dano causado ao réu.

Dessa maneira, o exercício da ação temerária, que abriga a dor e o dano para o acusado, dá azo à indenização, como defendido brilhantemente por Lúcio Palma da Fonseca:

"Basta o exercício da ação e os riscos a ela inerentes, para surgir a obrigação de indenizar, ou pela execução da medida, ou pela ocorrência de uma das hipóteses previstas em seu artigo." 37

Para Humberto Theodoro Junior, "dano que se há de indenizar é o resultante da execução da medida cautelar, isto é, aqueles prejuízos diretamente produzidos pelo cumprimento do mandato." 38

Compartilhando do mesmo horizonte jurídico, José Carlos Barbosa Moreira, aduna: "a responsabilidade do requerente tem como pressuposto a efetivação da providência cautelar." 39

Pela sentença improcedente, "do processo principal desfavorável ao requerente da cautela, e que engendra o dever de reparar, tanto pode ser de mérito (definitiva) como de preliminar (terminativa)." 40

37 Lúcio Palma da Fonseca, Tutela Cautelar: Responsabilidade Civil pelo Manejo Indevido de Liminares, Forense, 2004, p. 75.

38 Humberto Theodoro Junior, Processo Cautelar, $13^{2}$ ed., Livraria e Editora Universitária de Direito, 1992, p. 175.

39 José Carlos Barbosa Moreira. Responsabilidade do Requerente da Medida Cautelar. Ajuris. p. 109.

40 Humberto Theodoro Junior, cit. ant., p. 176. 


\section{IV - Conclusão}

Pelo exposto, concluímos que a utilização irresponsável da ação de improbidade administrativa, traz o dever do Poder Público, e do subscritor da natimorta ação, de indenizar o agente público e/ou ao terceiro, prejudicados pelo abuso do direito de acionar.

A utilização da faculdade de acionar pessoas não é ilimitado, decorrendo de uma criação intelectual do autor da lide. Havendo a turbação indevida do réu da ação de improbidade administrativa, julgada improcedente a posteriori, nasce o dever de indenizar. 